\title{
EATING ATTITUDES AND BODY IMAGE CONCERNS AMONG FEMALE ATHLETES FROM AESTHETIC SPORTS
}

\author{
Aleksandra ALEKSIĆ VELJKOVIĆ' ${ }^{1}$, Dušanka ĐUROVIĆ 2 , Filip BIRO ${ }^{3}$, Katarina \\ STOJANOVIĆ ${ }^{4}$, Predrag ILIĆ ${ }^{1}$
}

\footnotetext{
${ }^{1}$ Faculty of Sport and Physical Education, University of Niš, Niš, Serbia

${ }^{2}$ Faculty of Sport and Tourism, Educons University, Novi Sad, Serbia

${ }^{3}$ Faculty of Philosophy, University of Novi Sad, Novi Sad, Serbia

${ }^{4}$ Faculty of Philosophy, University of Niš, Niš, Serbia
}

\author{
Corresponding author: \\ Aleksandra ALEKSIĆ VELJKOVIĆ \\ Faculty of Sport and Physical Education, University of Niš, Čarnojevića 10a, Niš, Serbia \\ Phone: +38163443294 \\ E-mail: aleksic.veljkovic@gmail.com
}

\section{ABSTRACT}

Purpose: Research has suggested that in female athletes from aesthetic sports the prevalence of disordered eating attitudes is higher than in female athletes from other sports, mainly due to sport related factors like extreme training and practicing sports associated with high pressure and the idea that "being thin leads to success". The study was conducted to examine the prevalence of disturbed eating attitudes and their relationship with body image concerns in aesthetic and non-aesthetic female athletes.

Methods: 54 female athletes from aesthetic sports (synchronized swimming, artistic and rhythmic gymnastics, and dance), as well as 66 female athletes from non-aesthetic sports (volleyball, track and field, and soccer), completed the Eating Attitudes Test, the Body Shape Questionnaire, and the Figure Rating Scale (a visual scale used to assess body image dissatisfaction and body image dissatisfaction in relation to sport).

Results: The results indicated that aesthetic athletes scored significantly higher than those involved in non-aesthetic sports in Dieting, and in Body Image Dissatisfaction. Moreover, aesthetic athletes demonstrated significantly lower BMI mean scores. Significant correlations were found between Body Mass Index and Oral Control, Body Image Dissatisfaction and Body Image Dissatisfaction in relation to Sport, and between Eating Attitudes Test and the Body Shape Questionnaire results in aesthetic athletes. Furthermore, significant associations were found between Body Mass Index and Body Shape Questionnaire, Body Image Dissatisfaction and Body Image Dissatisfaction in relation to Sport, and Eating Attitudes Test and Body Shape Questionnaire in non-aesthetic athletes. 
Conclusion: The study confirmed the relationship between body image concerns and pathological eating attitudes among female aesthetic sport athletes.

Keywords: Aesthetic Sports, Body Shape Questionnaire, Eating Attitudes Test, Eating Disorders, Figure Rating Scale

\section{PREHRANJEVALNI VZORCI IN OBREMENJENOST S TELESNO PODOBO PRI ŠPORTNICAH IZ ESTETSKIH ŠPORTOV}

\section{IZVLE ČEK}

Cilj: Raziskave kažejo, da so moteni vzorci prehranjevanja bolj razširjeni pri športnicah iz estetskih športov kot pri športnicah iz drugih panog, predvsem zaradi dejavnikov, povezanih s samim športom, kot sta pretirana vadba ter ukvarjanje s športnimi zvrstmi, povezanimi z velikimi pritiski in prepričanjem, da "vitkost vodi do uspeha«. Pričujočo raziskavo smo izvedli, da bi preučili razširjenost motenih vzorcev prehranjevanja in njihovo povezanost z obremenjenostjo s telesno podobo pri športnicah iz estetskih športov in športnicah iz ostalih športnih panog.

Metode: 54 športnic iz estetskih športov (sinhronega plavanja, športne in ritmične gimnastike ter športnega plesa) in 66 športnic iz ostalih športnih zvrsti (odbojke, atletike in nogometa), je reševalo test o prehranjevalnih vzorcih, vprašalnik o postavi in vprašalnikz ocenjevalno lestvico shematskih postav (vizualno lestvico za ocenjevanje nezadovoljstva $s$ telesno podobo in nezadovoljstva s telesno podobo v povezavi s športom).

Rezultati: Pri športnicah, ki tekmujejo v estetskih športih, so bile dosežene vrednosti pri hujšanju in nezadovoljstvu s telesno podobo bistveno višje kot pri športnicah iz panog brez estetske komponente. Še več, športnice iz estetskih športnih panog so izkazovale bistveno nižje povprečne vrednosti ITM. Pri športnicah iz estetskih športov smo ugotovili pomembne korelacije med indeksom telesne mase in kontroliranjem vnosa hrane, med nezadovoljstvom s telesno podobo in nezadovoljstvom s telesno podobo $v$ povezavi s športom ter med rezultati testa o prehranjevalnih vzorcih in vprašalnika o postavi. Pri športnicah iz športnih zvrsti, neodvisnih od estetske komponente, pa smo ugotovili pomembne povezave med indeksom telesne mase in rezultati vprašalnika o postavi, med nezadovoljstvom s telesno podobo in nezadovoljstvom s telesno podobo $v$ povezavi s športom ter med rezultati testa o prehranjevalnih vzorcih in vprašalnika o postavi.

Zaključek: Raziskava je potrdila povezavo med obremenjenostjo s telesno podobo in patološkimi vzorci prehranjevanja pri športnicah iz estetskih športnih zvrsti.

Ključne besede: estetski športi, vprašalnik o postavi, test o prehranjevalnih vzorcih, motnje hranjenja, ocenjevalna lestvica shematskih postav 


\section{INTRODUCTION}

Eating disorders are generally characterized by severe disturbances in eating behavior and are associated with distorted body image (Chizawsky \& Newton, 2006). These disorders are characterized by preoccupation with food, body weight, and shape that are associated with behaviors such as starvation, fasting, binge eating, purging, and excessive exercise (Flament, Bissada, \& Spettigue, 2012). The core features of eating disorders include disturbances of body image (e.g., overvaluation of thinness, weight or shape concerns), over- or under-control of eating (e.g., severe dietary restriction, binge eating), and extreme behaviors to control weight or shape (e.g., compulsive exercise, purging) (Ahrberg, Trojca, Nasrawi, \& Vocks, 2011).

Body image is central to self-concept and has important implications for multiple areas of psychological functioning and quality of life (Sarwer, Thompson, \& Cash, 2005). Authors define body image as a multifaceted construct that refers to individuals' perceptions of, and attitudes toward, their own body, especially its appearance. Body dissatisfaction involves negative thoughts and feelings about one's body and a perceived discrepancy between current and "ideal" body size (Sarwer et al., 2005). Individuals with a negative body image often worry about their weight, are afraid to gain weight, and therefore diet more often than persons who have fewer weight concerns (de Bruin, Woertman, Bakker, \& Oudejans, 2009).

Participation in sports that require low body weight and overestimate aesthetics, using it as a criterion for obtaining good results in competitions - such as artistic gymnastics, synchronized swimming, running, and dance - is associated with a high incidence of eating disorders (Arcelus, Witcomb, \& Mitchell, 2014; Arthur-Cameselle, Sossin, \& Quatromoni, 2017; Doughty \& Hausenblas, 2005; Maya \& Moria, 2018; Petrie, 1993). For example, female collegiate athletes symptomatic for an eating disorder reported more perceived pressure to be thin than their asymptomatic peers (Greenleaf, Petrie, Carter, \& Reel, 2009).

There are multiple reasons why eating disorders are more frequent in certain sports. Most often, it is not a single element that causes eating disorders, but a series of specific factors. Those factors are mutually related, and they can be specific feelings or pressures to which a person is exposed. Some of the factors that can influence the development of eating problems are pressure to achieve success, a false conviction that the loss of weight will result in better performance, or a desire to impress fellow athletes, parents, and coaches (Bratland-Sanda \& Sundgot-Borgen, 2013). Characteristics of umpiring in aesthetic sports - i.e., the importance of the subjective opinion of the umpire about the virtuosity and the appearance of the athlete - can contribute to the pressure to reach and maintain an ideal weight (Ziegler et al., 1998). Ziegler et al. (1998) concluded that the dieting behaviors of figure skaters were not associated with perceptions of being overweight nor with a negative body image, contrary to the general belief that a negative body image and dieting are causally linked. Rather than believing that "thin is beautiful", gymnasts seemed convinced or persuaded that "thin is going to win" (deBruin, 2010). Specific risk factors about eating disorders in aesthetic sports involve 
the subjectivity of the judging, the advantages of small body mass, dominant aesthetic patterns, the young age of female athletes due to early specialization, and the outfits used in competitions (Francisco, Narciso, \& Alarcão, 2013).

Body dissatisfaction is often regarded as an essential factor typically associated with eating disorders (Torstveit \& Sundgot-Borgen, 2005). The higher probability that one will undertake attempts to lose weight, and dieting itself has been identified as another contributor to disordered eating (Zullig, Matthews-Ewald, \& Valois, 2016). Several studies have reported that elite female athletes from some sports dieted frequently and used pathogenic weight control methods despite being relatively satisfied with their bodies (Giel et al., 2016; Sundgot-Borgen \& Torstveit, 2010).

Research investigating eating disorder occurrence in sport has shown an increased prevalence in elite female athletes in comparison with non-elite athletes or non-athletes. It was suggested that future studies develop and examine multi-factorial risk factor models for eating disorders in athletes (Bratland-Sanda \& Sundgot-Borgen, 2013). The authors are trying to create a universal model that represents and explains the structure of eating attitudes. Factors like body image dissatisfaction, weight concerns, and actual dieting behavior are almost always part of these models and a negative body image is found to be a very potent, well-supported risk factor (Perini et al., 2009; Ravaldi et al., 2003).

Our study aims to explore the relationship between body image concerns and eating disorders among female aesthetic sport athletes. The relationship between these two constructs can place body image concerns as a potential tool for the prediction of eating disorders.

\section{METHOD}

\section{Sample}

The study group included 54 female athletes (aged $19 \pm 3$ years), affiliated to clubs of different aesthetic sports in Serbia (23 from artistic and rhythmic gymnastics, 20 from dance, and 11 from synchronized swimming). They reported an average training period of $7.40 \pm 7.41$ years, a total of $8.25 \pm 3.30$ hours of practice a week, and the start of the sport career at $6.33 \pm 2.45$ years.

The control group was formed by 66 female athletes from non-aesthetic sports (aged $20 \pm 3$ years), consisting of 20 athletes from volleyball, 22 from soccer and 24 from basketball. They reported a training period of $6.8 \pm 4.5$ years, and a total of $7 \pm$ 3.50 hours of practice a week, and the start of the sport career at $8 \pm 3.5$ years.

All the participants filled in the Informed Consent form and the study was conducted according to the Declaration of Helsinki and approved by the Ethics Committee of the Faculty of Sports and Physical Education, University of Niš (Number 05-2115). 


\section{Anthropometric characteristics}

All athletes completed a questionnaire that included age, weight, and height information, as well as training and competition details. Participants' Body Mass Index (BMI) was calculated as the ratio of body weight to the squared standing height $(\mathrm{kg} /$ $\mathrm{m} 2$ ).

Underweight, normal weight, overweight, and obesity were identified through ageand gender-specific national and international cut-off points, which correspond with BMI values of less than $18 \mathrm{~kg} / \mathrm{m} 2$ (underweight), $18-25 \mathrm{~kg} / \mathrm{m} 2$ (normal), $25-30 \mathrm{~kg} / \mathrm{m} 2$ (overweight), and more than $30 \mathrm{~kg} / \mathrm{m} 2$ (obesity).

\section{Instruments}

\section{Eating Attitudes Test-26 (EAT-26)}

EAT-26 is a self-report questionnaire used internationally to identify and assess disturbances in eating attitudes and behaviors and is also useful for following up the progression of clinical cases. The questionnaire consists of 26 items with three sub-scales: Dieting, Bulimia and Food preoccupation, and Oral Control. If the total score is higher than 20, EAT-26 is considered to be positive, thus confirming the presence of abnormal dietary attitudes, and the risk of developing an eating disorder (Garner \& Garfinkel, 1997). The inventory uses a 6-point, Likert-type scale ( $1=$ always, $2=$ very often, $3=$ often, $4=$ sometimes, $5=$ seldom, and $6=$ never $)$.

\section{Body Shape Questionnaire (BSQ)}

To assess the degree of dissatisfaction with body image, the Body Shape Questionnaire - BSQ was used, which measures the concern one has with hisher own body shape, self-depreciation due to physical aspects and to the feeling of being fat. The questionnaire differentiates two aspects of body image: the accuracy of body size estimates, and the feelings towards the body (dissatisfaction or depreciation of one's fitness). The questionnaire includes 34 items, and uses a 6-point, Likert-type scale $(1=$ never, $2=$ seldom, $3=$ sometimes, $4=$ often, $5=$ very often, and $6=$ always $)$. The items' scores are summed, and a total score is calculated for each individual. A total score lower than or equal to 80 is considered normal; i.e., no distortion of body image. A score between 81 and 110 means mild body image distortion; scores between 111 and 140 indicate moderate distortion; and over 140 severe body image distortion (Cordás \& Castilho, 1994). 


\section{Figure rating scale}

A figure rating scale, developed by Stunkard, Sørensen, and Schulsinger (1983) was used to assess body image. Gender-specific drawing consisted of 9 schematic figures ranging from 1 (very underweight) to 9 (very overweight). The results are presented as the difference between the current and the desired size perceptions (current body size score minus desired body size score); and also, between athletes' actual and perceived ideal body for their sport. A discrepancy score is interpreted as a measure of body image dissatisfaction (BID) and body image dissatisfaction in relation to sport (BIDS).

\section{Statistical analysis}

Descriptive statistics and T-test for small independent samples were used to examine differences in the variables recorded for the athletes involved in both aesthetic and non-aesthetic sports. Pearson correlation coefficient was calculated to examine the relationship between the variables, and the Kruskal-Wallis test to compare three groups of participants, according to the criteria of BMI. Calculation of parameters and applied statistics were performed with the use of software SPSS 20, with a significance level of $\mathrm{p} \leq 0.05$.

\section{RESULTS}

Table 1 presents descriptive statistics for the groups and the whole sample, as well as the statistical significance (p) of T-test, showing differences between our two groups.

The results show that the group of aesthetic sports had a significantly lower mean score of BMI, and a significantly higher mean score of EAT-Dieting, and BID (Table 1). The difference between the mean scores of BSQ was on the border of significance. Consequently, we can conclude that girls from the group of aesthetic sports were significantly more dissatisfied with their body image and tended to apply dieting. Furthermore, it is important to stress that in the aesthetic sport group we found 12 underweight girls (none in the control group), and 7 with BMI $<17 \mathrm{~kg} / \mathrm{m} 2-$ which is one of the DSM-5 criteria for the diagnosis of anorexia nervosa. 
Table 1. Descriptive statistics and T-test between groups

\begin{tabular}{|c|c|c|c|c|c|c|c|}
\hline Variables & के & Z & $\stackrel{\Xi}{E}$ & 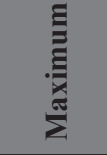 & 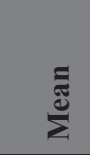 & के & $=$ \\
\hline \multirow{3}{*}{ BMI } & Aesthetic & 54 & 14.72 & 28.00 & 20.54 & 2.97 & \multirow{3}{*}{0.007} \\
\hline & Non-aesthetic & 66 & 18.19 & 28.69 & 21.84 & 2.23 & \\
\hline & Total sample & 120 & 14.72 & 28.69 & 21.25 & 2.66 & \\
\hline \multirow{3}{*}{ EAT-26 } & Aesthetic & 54 & .00 & 52.00 & 10.52 & 8.79 & \multirow{3}{*}{0.106} \\
\hline & Non-aesthetic & 66 & .00 & 38.00 & 8.23 & 6.63 & \\
\hline & Total sample & 120 & .00 & 52.00 & 9.26 & 7.73 & \\
\hline \multirow{3}{*}{ EAT-Dieting } & Aesthetic & 54 & .00 & 30.00 & 6.13 & 5.92 & \multirow{3}{*}{0.021} \\
\hline & Non-aesthetic & 66 & .00 & 23.00 & 3.89 & 4.52 & \\
\hline & Total sample & 120 & .00 & 30.00 & 4.90 & 5.29 & \\
\hline \multirow{3}{*}{$\begin{array}{l}\text { EAT-Bulimia } \\
\text { and Food } \\
\text { Preoccupation }\end{array}$} & Aesthetic & 54 & .00 & 9.00 & 1.26 & 2.23 & \multirow{3}{*}{0.116} \\
\hline & Non-aesthetic & 66 & .00 & 12.00 & 1.97 & 2.61 & \\
\hline & Total sample & 120 & .00 & 12.00 & 1.65 & 2.46 & \\
\hline \multirow{3}{*}{$\begin{array}{l}\text { EAT-Oral } \\
\text { Control }\end{array}$} & Aesthetic & 54 & .00 & 13.00 & 3.13 & 3.06 & \multirow{3}{*}{0.119} \\
\hline & Non-aesthetic & 66 & .00 & 11.00 & 2.36 & 2.28 & \\
\hline & Total sample & 120 & .00 & 13.00 & 2.71 & 2.67 & \\
\hline \multirow{3}{*}{$\begin{array}{l}\text { Body Shape } \\
\text { Questionnaire } \\
\text { (BSQ) }\end{array}$} & Aesthetic & 54 & 51.00 & 132.00 & 79.52 & 18.25 & \multirow{3}{*}{0.071} \\
\hline & Non-aesthetic & 66 & 52.00 & 120.00 & 74.29 & 13.19 & \\
\hline & Total sample & 120 & 51.00 & 132.00 & 76.64 & 15.82 & \\
\hline \multirow{3}{*}{$\begin{array}{l}\text { Body Image } \\
\text { Dissatisfaction } \\
\text { (BID) }\end{array}$} & Aesthetic & 54 & .00 & 3.00 & 1.06 & .83 & \multirow{3}{*}{0.002} \\
\hline & Non-aesthetic & 66 & .00 & 3.00 & .62 & .70 & \\
\hline & Total sample & 120 & .00 & 3.00 & .82 & .79 & \\
\hline \multirow{3}{*}{$\begin{array}{l}\text { Body Image } \\
\text { Dissatisfaction } \\
\text { in relation to } \\
\text { Sport (BIDS) }\end{array}$} & Aesthetic & 54 & .00 & 3.00 & .87 & .95 & \multirow{3}{*}{0.372} \\
\hline & Non-aesthetic & 66 & .00 & 3.00 & .73 & .79 & \\
\hline & Total sample & 120 & .00 & 3.00 & .79 & .87 & \\
\hline
\end{tabular}


Table 2. Correlation matrix for aesthetic sports

\begin{tabular}{|l|c|c|c|c|c|c|c|}
\hline Variables & BMI & EAT-26 & Dieting & Bulimia & $\begin{array}{c}\text { Oral } \\
\text { control }\end{array}$ & BSQ & BID \\
\hline BMI & - & & & & & & \\
\hline EAT-26 & -.077 & - & & & & & \\
\hline EAT-Dieting & .100 & $.927 * *$ & - & & & & \\
\hline EAT-Bulimia & .081 & $.507 * *$ & $.320^{*}$ & - & & & \\
\hline $\begin{array}{l}\text { EAT-Oral } \\
\text { Control }\end{array}$ & $-.472^{* *}$ & $.708^{* *}$ & $.494^{* *}$ & .108 & - & & \\
\hline BSQ & .106 & $.489 * *$ & $.513^{* *}$ & .116 & $.326^{*}$ & - & \\
\hline BID & $.342^{* *}$ & .181 & .239 & .164 & -.062 & $.297 *$ & - \\
\hline BIDS & $.287 *$ & .125 & .174 & .238 & -.150 & $.309 *$ & $.437^{* *}$ \\
\hline
\end{tabular}

** Correlation is significant at the 0.01 level (2-tailed).

* Correlation is significant at the 0.05 level (2-tailed).

Table 3. Correlation matrix for non-aesthetic sports

\begin{tabular}{|l|c|c|c|c|c|c|c|}
\hline Variables & BMI & EAT-26 & Dieting & Bulimia & $\begin{array}{c}\text { Oral } \\
\text { control }\end{array}$ & BSQ & BID \\
\hline BMI & - & & & & & & \\
\hline EAT-26 & .041 & - & & & & & \\
\hline EAT-Dieting & .125 & $.899 * *$ & - & & & & \\
\hline EAT-Bulimia & .056 & $.757 * *$ & $.597 * *$ & - & & & \\
\hline $\begin{array}{l}\text { E A T - O r a I } \\
\text { Control }\end{array}$ & -.193 & $.260^{*}$ & -.050 & -.125 & - & & \\
\hline BSQ & $.267 *$ & $.490^{* *}$ & $.492 * *$ & $.341 * *$ & .059 & - & \\
\hline BID & $.371 * *$ & -.021 & .016 & .011 & -.106 & $.307 *$ & - \\
\hline BIDS & $.263 *$ & .134 & $.253^{*}$ & $.335^{* *}$ & -.182 & .122 & $.505^{* *}$ \\
\hline
\end{tabular}

** Correlation is significant at the 0.01 level (2-tailed).

* Correlation is significant at the 0.05 level (2-tailed). 
By considering the results of correlation analysis in the sample of aesthetic sports (Table 2), we can conclude that a low BMI highly correlates with the tendency toward oral (food) control (examples of items in EAT-Oral Control: "I avoid eating when I'm hungry."; "I can control myself well with food."); the higher the BMI, the more body image dissatisfaction exists. Interestingly, the correlation between BMI and body shape concerns (BSQ) is low (0.106), but the correlation between body shape concerns and dieting is highly significant and positive. Girls with low BMI are satisfied with their body shape and tend to keep it through strong feeding control; but, on the other hand, when they are worried about their body shape, they apply diets.

The results of correlation analysis in the sample of non-aesthetic sports (Table 3) show high correlation between BMI and body shape concerns (BSQ), as well as between BMI and body image dissatisfaction. Interestingly, body image dissatisfaction in connection with sport is most related to the bulimic type of controlling eating behavior (examples of items in EAT-Bulimia and Food Preoccupation: "I vomit after eating."; "Thinking about food preoccupies me.").

To further analyze the behavior of our subjects depending on the BMI category, we also performed a Kruskal-Wallis test for three groups: 1 - underweight, 2 - normal, and 3 - overweight (see Table 4).

The results of the Kruskal-Wallis test also confirmed the underweight girls' readiness for extreme nutritional control (to maintain their low body weight), as well as body image dissatisfaction in relation to sport found in overweight girls.

Table 4. Kruskal-Wallis test

\begin{tabular}{|c|c|c|c|c|c|c|c|}
\hline & 站 & $\overline{\overline{0}} \overline{\grave{0}}$ & 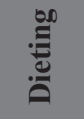 & 葛 & O & $\stackrel{\bar{\theta}}{\oplus}$ & $\stackrel{0}{\hat{n}}$ \\
\hline Kruskal-Wallis H & 2.549 & 9.829 & .528 & 3.879 & 3.118 & 3.701 & 7.970 \\
\hline df & 2 & 2 & 2 & 2 & 2 & 2 & 2 \\
\hline Asymp. Sig. & .280 & .007 & .768 & .144 & .210 & .157 & .019 \\
\hline
\end{tabular}




\begin{tabular}{|c|c|c|c|}
\hline \multicolumn{4}{|c|}{ Ranks } \\
\hline & Group & $\mathbf{N}$ & Mean Rank \\
\hline \multirow[t]{4}{*}{ EAT-26 } & 1 & 12 & 75.67 \\
\hline & 2 & 95 & 58.77 \\
\hline & 3 & 13 & 59.15 \\
\hline & Total & 120 & \\
\hline \multirow[t]{4}{*}{ Oral Control } & 1 & 12 & 85.83 \\
\hline & 2 & 95 & 59.64 \\
\hline & 3 & 13 & 43.42 \\
\hline & Total & 120 & \\
\hline \multirow[t]{4}{*}{ Dieting } & 1 & 12 & 65.92 \\
\hline & 2 & 95 & 59.35 \\
\hline & 3 & 13 & 63.92 \\
\hline & Total & 120 & \\
\hline \multirow[t]{4}{*}{ Bulimia } & 1 & 12 & 43.29 \\
\hline & 2 & 95 & 62.04 \\
\hline & 3 & 13 & 65.12 \\
\hline & Total & 120 & \\
\hline \multirow[t]{4}{*}{ BSQ } & 1 & 12 & 66.46 \\
\hline & 2 & 95 & 57.79 \\
\hline & 3 & 13 & 74.77 \\
\hline & Total & 120 & \\
\hline \multirow[t]{4}{*}{ BID } & 1 & 12 & 58.33 \\
\hline & 2 & 95 & 58.54 \\
\hline & 3 & 13 & 76.81 \\
\hline & Total & 120 & \\
\hline \multirow[t]{4}{*}{ BIDS } & 1 & 12 & 58.33 \\
\hline & 2 & 95 & 58.54 \\
\hline & 3 & 13 & 76.81 \\
\hline & Total & 120 & \\
\hline
\end{tabular}




\section{DISCUSSION}

This study confirmed the relationship between body image dissatisfaction and pathological eating attitudes among female aesthetic sport athletes. Results show that athletes in both groups with a higher BMI are concerned about their appearance, dissatisfied with their body in connection with sport, and are inclined to use dieting or compensatory behavior to reduce their weight, but the concern is more prevalent in the group of aesthetic sports leading to pathogenic eating habits. Athletes in the group of aesthetic sports have significantly lower BMI than athletes from non-aesthetic sports - some of them even fit the low body weight DSM-5 criterion for Anorexia Nervosa. Paradoxically, underweight girls are satisfied with their body shape, and use extreme diet control to keep their bodies thin. Using such pathological eating habits, those girls are at high risk for developing an eating disorder.

Due to the seriousness of eating disorders, and their frequent occurrence in sports, it is important to examine and understand why athletes seem to be more at risk compared to non-athletes (Bratland-Sanda \& Sundgot-Borgen, 2013), especially in aesthetic sports, where the risk is even higher, because of the aesthetic component in performance. Besides the aesthetic component, risk factors might also be weight regulation, dieting, and pressure to lose weight, personality traits, early start of sport-specific training, injuries, symptoms of overtraining, impression motivation, threat perception, and the impact of coaching behavior (Bratland-Sanda \& Sundgot-Borgen, 2013). For all these sports, especially gymnastics, it is important to start a sport-specific career very early. The athletes in this investigation reported the start of their sport career at the age of $6.33 \pm 2.45$ years. The problem with the early start of sport-specific training is the risk of choosing a sport inappropriate for the athlete's body type (Sundgot-Borgen, 1994). Pubertal changes can affect the performance, so the earlier studies reported the importance to start primary prevention as early as 9-11 years, in order to protect athletes from different factors that can predispose them to develop eating disorders and bad eating habits (Coelho et al., 2014). Furthermore, engaging in sports associated with high levels of body preoccupation at an early and vulnerable age is also suggested as a factor for increasing the risk of eating disorders (Bratland-Sanda \& Sundgot-Borgen, 2013; Currie, 2010). The regulation of body mass is a critical issue for the athletes and attention must be paid to their strategies for weight control. For this reason, educating athletes, as well as coaches and sport functionaries, regarding the causes and consequences of eating disorders seems to be a necessary form of prevention of these.

Limitations in the present study include a small sample size from only one country where participants reported their height and weight and were at different levels of competition, from three different aesthetic sports. 


\section{CONCLUSION}

The results of our study show that girls from aesthetic sports fight hard to make their bodies thin. If they are unsuccessful in that endeavor, they show dissatisfaction with their own bodies and use rigorous forms of dieting. This puts them at a greater risk of developing eating disorders, some of them already meeting the low weight criterion for anorexia nervosa.

\section{REFERENCES}

Ahrberg, M., Trojca, D., Nasrawi, N., \& Vocks, S. (2011). Body image disturbance in binge eating disorder: a review. European Eating Disorders Review, 19(5), 375-381. https://doi.org/10.1002/erv.1100.

Arcelus, J., Witcomb, G. L., \& Mitchell, A. (2014). Prevalence of eating disorders amongst dancers: a systemic review and meta-analysis. European Eating Disorders Review, 22(2), 92-101. https://doi.org/10.1002/erv.2271.

Arthur-Cameselle, J., Sossin, K., \& Quatromoni, P. (2017). A qualitative analysis of factors related to eating disorder onset in female collegiate athletes and non-athletes. Eating Disorders, 25(3), 199-215. https://doi.org/10.1080/10640266.2016.1258940.

Bratland-Sanda, S., \& Sundgot-Borgen, J. (2013). Eating disorders in athletes: overview of prevalence, risk factors and recommendations for prevention and treatment. European Journal of Sport Science, 13(5), 499-508. https://doi.org/10.1080/17461391.2012.7 40504.

Chizawsky, L. L., \& Newton, M. S. (2006). Identification and treatment in obstetrical patients. AWHONN lifelines, 10(6), 483-488. https://doi.org/10.1111/j.15526356.2006.00097.x.

Coelho, G. M., da Silva Gomes, A. I., Ribeiro, B. G., \& de Abreu Soares, E. (2014). Prevention of eating disorders in female athletes. Open Access Journal of Sports Medicine, 5, 105-113. https://doi.org/10.2147/OAJSM.S36528.

Cordás, T. A., \& Castilho, S. (1994). Imagem corporal nos transtornos alimentares: instrumento de avaliação: Body Shape Questionnaire. Psiquiatria biológica, 2(1), 17-21.

Currie, A. (2010). Sport and eating disorders-understanding and managing the risks. Asian Journal of Sports Medicine, 1(2), 63-68. https://doi.org/10.5812/asjsm.34864.

de Bruin, A. K., Woertman, L., Bakker, F. C., \& Oudejans, R. R. (2009). Weight-related sport motives and girls' body image, weight control behaviors, and self-esteem. Sex Roles, 60(9-10), 628-641. https://doi.org/10.1007/s11199-008-9562-8.

de Bruin, A. P. (2010). Thin is going to win? Disordered eating in sport. PhD Thesis. Vrije Universiteit Amsterdam. Retrieved from https://research.vu.nl/en/publications/thin-is-going-to-win-disordered-eating-in-sport.

Doughty, J. H., \& Hausenblas, H. A. (2005). A longitudinal examination of disordered eating correlates in collegiate gymnasts. Women in Sport \& Physical Activity Journal, 14(1), 52-61.

Flament, M. F., Bissada, H., \& Spettigue, W. (2012). Evidence-based pharmacotherapy of eating disorders. International Journal of Neuropsychopharmacology, 15(2), 189-207. https://doi.org/10.1017/S1461145711000381. 
Francisco, R., Narciso, I., \& Alarcao, M. (2013). Individual and relational risk factors for the development of eating disorders in adolescent aesthetic athletes and general adolescents. Eating and Weight Disorders-Studies on Anorexia, Bulimia and Obesity, 18(4), 403-411. https://doi.org/10.1007/s40519-013-0055-6.

Garner, D. M., \& Garfinkel, P. E. (Eds.). (1997). Handbook of treatment for eating disorders. New York; London: Guilford Press.

Giel, K. E., Hermann-Werner, A., Mayer, J., Diehl, K., Schneider, S., Thiel, A., ... \& GOAL Study Group. (2016). Eating disorder pathology in elite adolescent athletes. International Journal of Eating Disorders, 49(6), 553-562. https://doi.org/10.1002/ eat.22511.

Greenleaf, C., Petrie, T. A., Carter, J., \& Reel, J. J. (2009). Female collegiate athletes: Prevalence of eating disorders and disordered eating behaviors. Journal of American College Health, 57(5), 489-496. https://doi.org/10.3200/JACH.57.5.489-496.

Harriger, J. A. (2009). Risk and protective factors in women's artistic gymnastics: The relationship to disordered eating and negative body image. ProQuest Dissertation. The University of New Mexico. Retrieved from: https://search.proquest.com/docview $/ 304947933$ ?pqorigsite $=$ gscholar\&fromopenview $=$ true.

Maya, M., \& Moria, G. (2018). Prevalence of Disordered eating behaviors and body dissatisfaction among Israeli adolescent female aesthetic athletes. EC Psychology and Psychiatry, 7, 37-46.

Perini, T. A., Vieira, R. S., Vigário, P. D. S., Oliveira, G. L. D., Ornellas, J. D. S., \& Oliveira, F. P. D. (2009). Eating disorders in elite synchronized swimmers. Revista Brasileira de Medicina do Esporte, 15(1), 54-57. https://doi.org/10.1590/S151786922009000100012.

Petrie, T. A. (1993). Disordered eating in female collegiate gymnasts: Prevalence and personality/attitudinal correlates. Journal of Sport and Exercise Psychology, 15(4), 424-436. https://doi.org/10.1123/jsep.15.4.424.

Ravaldi, C., Vannacci, A., Zucchi, T., Mannucci, E., Cabras, P. L., Boldrini, M., ... \& Ricca, V. (2003). Eating disorders and body image disturbances among ballet dancers, gymnasium users and body builders. Psychopathology, 36(5), 247-254. https://doi. org/10.1159/000073450.

Sarwer, D. B., Thompson, J. K., \& Cash, T. F. (2005). Body image and obesity in adulthood. Psychiatric Clinics, 28(1), 69-87. https://doi.org/10.1016/j.psc.2004.09.002.

Stunkard, A. J., Sørensen, T. I., \& Schlusinger, F. (1983). Use of the Danish Adoption Register for the study of obesity and thinness. In S. S. Kety, L. P. Rowland, R. L. Sidman, $\&$ S. W. Matthysse (Eds.), The genetics of neurological and psychiatric disorders. New York, NY: Raven Press, 115-120.

Sundgot-Borgen, J., \& Torstveit, M. K. (2010). Aspects of disordered eating continuum in elite high-intensity sports. Scandinavian Journal of Medicine \& Science in Sports, 20(2), 112-121. https://doi.org/10.1111/j.1600-0838.2010.01190.x.

Sundgot-Borgen, J. (1994). Risk and trigger factors for the development of eating disorders in female elite athletes. Medicine \& Science in Sports \& Exercise. 26(4), 414-419. https://doi.org/10.1249/00005768-199404000-00003.

Torstveit, M. K., \& Sundgot-Borgen, J. (2005). The female athlete triad: are elite athletes at increased risk? Medicine \& Science in Sports \& Exercise, 37(2), 184-193. https://doi. org/10.1249/01.MSS.0000152677.60545.3A. 
Ziegler, P. J., Khoo, C. S., Sherr, B., Nelson, J. A., Larson, W. M., \& Drewnowski, A. (1998). Body image and dieting behaviors among elite figure skaters. International Journal of Eating Disorders, 24(4), 421-427. https://doi.org/10.1002/(SICI)1098-108X(199812)24:4<421::AID-EAT9>3.0.CO;2-H.

Zullig, K. J., Matthews-Ewald, M. R., \& Valois, R. F. (2016). Weight perceptions, disordered eating behaviors, and emotional self-efficacy among high school adolescents. Eating behaviors, 21, 1-6. https://doi.org/10.1016/j.eatbeh.2015.11.007. 